\title{
Constitutional overperformance: an empirical study of de facto protection of rights with no de jure equivalents
}

\author{
Katarzyna Metelska-Szaniawska ${ }^{1} \cdot$ Anna Lewczuk $^{1}$ (D)
}

Accepted: 19 January 2022 / Published online: 12 February 2022

(c) The Author(s) 2022

\begin{abstract}
In this paper we aim to contribute to the debate on successful enforcement of constitutional rules and its determinants by extending the focus to the phenomenon of constitutional overperformance, which arises when countries that do not include certain de jure rights in their constitutions, nevertheless de facto observe them. Firstly, we provide evidence that constitutional overperformance is a common phenomenon around the globe and it demonstrates high variation. Secondly, we identify factors which contribute to it. In particular, more constitutional overperformance is found in countries with older and less comprehensive constitutions, a high degree of democratization and a more robust civil society, plagued by less political conflict. Spatial interdependence effects are also identified confirming the diffusion of constitutional overperformance between countries. We base the conclusions on an empirical study conducted for a global sample of more than 100 countries.
\end{abstract}

Keywords Constitutional overperformance $\cdot$ Constitutional enforcement · Democracy $\cdot$ Spatial regression models

JEL Classification D02 $\cdot \mathrm{H} 11 \cdot \mathrm{K} 19 \cdot \mathrm{K} 38$

\section{Introduction}

It is no longer much of a controversy among economists that "constitutions matter", also with regard to the behavior of markets and economic outcomes. Seminal theoretic contributions by the "father" of Constitutional Economics-Buchanan (e.g. Buchanan \& Tullock, 1962), as well as numerous empirical works (see e.g. Persson and Tabellini, 2003; or a survey by Voigt, 2011), view the constitution as

Anna Lewczuk

alewczuk@wne.uw.edu.pl

Katarzyna Metelska-Szaniawska

kmetelska@wne.uw.edu.pl

1 Faculty of Economic Sciences, University of Warsaw, Warsaw, Poland 
a mechanism allowing to counteract time-inconsistency problems connected with drafting and implementing economic policy. Containing rules that impose constraints on activity of state authorities (e.g. separation of powers, bills of rights, an independent constitutional judiciary, constitutional budgetary limits), the constitution enables turning promises made by representatives of state power into credible commitments.

A new strand of empirical literature has recently been developing in this area, focusing on the problem of constitutional enforcement. A number of empirical studies have indicated the relevance of de facto constitutional rules, i.e. the way constitutional constraints actually function (dependent on compliance and enforcement) and not necessarily de jure rules which have been formalized in constitution texts, for economic outcomes (e.g. Blume et al., 2009-with regard to direct democracy mechanisms, Voigt et al., 2015-concerning judicial independence; Bjoernskov, 2015 on property rights; Spruk, 2016 on political institutions; Lewczuk, 2019 on human rights protection). More and more literature aiming to identify the factors explaining both types of rules has also emerged, including studies interested in finding whether the text of constitutions matters for de facto operation of constitutional rules (e.g. Elkins et al., 2013; Melton, 2013; Melton \& Ginsburg, 2014; MetelskaSzaniawska and Lewkowicz, 2021). The de jure-de facto gap, its potential effects and determinants, have also recently received some attention (e.g. Voigt, 2021), in particular in studies concentrating on the so-called constitutional underperformance, i.e. the failure to respect de jure constitutional rights and freedoms (e.g. Chilton \& Versteeg, 2016; Law \& Versteeg, 2013).

In this paper we aim to study a related phenomenon, which has gone to a great extent unnoticed by the literature, namely "constitutional overperformance", i.e. the situation when certain constitutional rights and/or freedoms are factually enjoyed by citizens in a given country although they are not included in this country's de jure constitution. Law and Versteeg (2013) make a first attempt to trace this phenomenon around the globe based on a measure of constitutional performance which they construct for a selection of 15 constitutional rights and freedoms. They observe constitutional overperformance in some countries with relatively old constitutions (and, therefore, containing less de jure rights), such as the United States or Norway, as well as in some democracies that have historically lacked a bill of rights, e.g. Australia or United Kingdom. We follow Law and Versteeg's (2013) approach in operationalizing constitutional overperformance based on protection of constitutional rights but broaden the search for its potential determinants beyond the lack of de jure institutionalization problem. Based on suggestions from cross-disciplinary and economics literature on the protection/violation of rights, we ask whether there exist any systematic patterns of characteristics of countries that overperform at the constitutional level. We group the suspects into 3 categories. Firstly, we focus on aspects connected directly with constitutions as legal acts and the lack of de jure institutionalization, i.e. the constitution's comprehensiveness (how many rights it includes) and its age. Secondly, we examine countries' institutional and socio-economic characteristics that may provide favorable conditions for protecting/enjoying rights even when the latter lack de jure codification in the constitution. These are factors affecting the costs and/or benefits of rights protection relating, e.g., to the 
country's democratization level (and various features thereof), the role of judges and their discretion in the interpretation of the constitution (primarily at the constitutional court), the economic development of a country, presence of political conflicts, as well as adoption of international covenants imposing the protection of rights under the threat of costly sanctions. Finally, we ask whether spatial effects are identifiable, i.e. does it matter for constitutional performance in one country, even when no de jure rights of a given kind exist in its constitution text, that citizens in the neighboring countries de facto enjoy these rights (and, if so, via which channels this diffusion of overperformance takes place). The spatial analysis approach is not only a way to answer the above questions about spatial interdependence and a relatively novel tool in constitutional economics studies but also comes with an advantage of tackling part of the potentially involved endogeneity problem.

The paper is structured as follows. In Sect. 2 we present the phenomenon of constitutional overperformance, its definition, measurement and distribution around the globe. Section 3 discusses our conceptual framework for the study of potential determinants of constitutional overperformance, building on the existing literature on the protection of rights and constitutional enforcement and combining this framework with aspects of institutional and policy diffusion. In Sect. 4 we verify the significance of these determinants of constitutional overperformance in an empirical study for a global sample. We employ both ordinary panel data regression techniques, as well as broaden the empirical approach to include spatial effects and provide an additional robustness check. The paper finishes with conclusions.

\section{Constitutional overperformance in the world}

Constitutional underperformance around the world, i.e. most generally, the failure to enforce certain constitutional provisions, is much better documented (see, in particular, Law \& Versteeg, 2013 and literature mentioned therein) than constitutional overperformance. In this section we present a more systematic view of the latter, as a background for our empirical study conducted further in the paper.

\subsection{The constitutional overperformance measure}

As already mentioned, the concept of constitutional overperformance is linked to the gap that arises between de facto constitutional rules functioning in a given country and the de jure constitutional rules laid down in this country's constitution text. To the best of the authors' knowledge, the literature has so far put forward only one measure of constitutional overperformance. This measure, proposed by Law and Versteeg (2013), focuses on the extent to which countries respect rights that are not found in their constitutions. Its construction is based on a representative sample from 3 categories of rights-personal integrity rights, civil and political freedoms, and socio-economic and group rights - and constrained by the necessity of choosing de jure rights for which corresponding de facto data could be found. As a result, the following 15 rights are included: prohibition of arbitrary arrest and/or detention, 
prohibition of torture, right to habeas corpus, fair trial rights, prohibition of death penalty (falling within the category of personal integrity rights); freedom of assembly and/or association, freedom of movement, freedom of religion, right to vote, freedom of the press and/or expression (civil and political freedoms); right to health, right to education, gender equality in marriage, gender equality in labor relations, general protection of minority rights or right of minorities to be represented in government (socio-economic and group rights). Each country receives a constitutional overperformance score between 0 and 1 which is equal to the proportion of de jure omitted rights that were nevertheless factually protected. ${ }^{1}$

The measure proposed by Law and Versteeg (2013) is certainly limited and this in a number of ways. In its de facto dimension the indicator is based on the Cingranelli et al. (2014) human rights data that has been criticized, in particular for the limited reliability of the expert coding on which it is based, and must be interpreted with caution. By construction the indicator also has an upper and lower bound, what might pose additional challenges for its statistical analysis. It also focuses only on a single constitutional component - the protection of rights (and, furthermore, the selection of included rights is limited to 15 based on data availability, as explained in the previous paragraph). The problem of constitutional overperformance can, obviously, relate to other elements of constitutions, such as structural rules (e.g. factual and formal separation of powers), constitutional review (de facto and de jure judicial independence), or others. The mechanisms behind the emergence of gaps between de jure and de facto (leading to over- or underperformance), however, are not homogenous for different constitutional rules and do not allow for analysis within a single conceptual framework.

Finally, the discussed measure of constitutional overperformance falls short of accounting for any constitutional underperformance that could simultaneously arise for rights which have been included in the given country's constitution but are factually not enforced. In consequence, the identified overperformance effect cannot be regarded as reflecting the overall degree of (over-)protection of rights in a given country but only relates to the situation when certain rights are de facto protected even though the constitution does not contain their de jure equivalents. Given the evidence presented in the subsequent section that not coding certain rights in countries' constitutions is common practice around the world, investigating potential mechanisms facilitating de facto protection of these uncoded rights is, nevertheless, certainly a task worth undertaking.

To conclude, the measure of constitutional overperformance proposed by Law and Versteeg (2013) and applied in this paper captures what could be called a microconstitutional overperformance effect arising when a country lacking a specific de jure constitutional rule (in our case: right) protects this rule/right in practice, and not a macro-constitutional overperformance effect relating to the de jure-de facto gap

\footnotetext{
${ }^{1}$ For example, a country which includes 12 of the 15 rights enumerated above in the text in its constitution (i.e. 3 rights are not included) and factually protects 1 of the non-included rights, will receive an overperformance score of 0.333 .
} 
for the entire constitutional rule-framework of a country. ${ }^{2}$ The interest in this paper is to identify factors constituting favorable conditions for such a micro-constitutional overperformance effect.

\subsection{Patterns of constitutional overperformance (1981-2010)}

According to the most recent data of Law and Versteeg (2013) for the year 2010, there are 19 countries in the world that obtain the highest possible score of 1 on constitutional overperformance. Most of them are located in Europe (Bulgaria, Denmark, Finland, Iceland, Italy, Luxembourg, Malta, The Netherlands, Norway, Portugal, Sweden, Ukraine, and United Kingdom) and the remaining ones are: Canada, Cape Verde, Namibia, New Zealand, Palau, and South Korea. Accounting for the fact that the less rights that a country promises in its constitution, the more impressive it becomes that it nevertheless upholds them in practice, it is reasonable to supplement this picture with a list of best constitutional overperformers among those countries that contain 8 or less of the 15 rights mentioned above in their constitution texts. ${ }^{3}$ For the most recent period (2010) the top 10 constitutional overperformers conceived in this way are the following: Denmark, Norway, France, Australia, Bosnia and Herzegovina, United States, Comoros, Laos, Morocco, and Brunei. This fragmented information already suggests that constitutional overperformance is not simply a regional phenomenon but it is present on various continents and in countries of differing size and other characteristics such as regime type or economic development.

Figure 1 shows the distribution of constitutional overperformance scores within our sample of 151 countries of the world in the time period 1981-2010. Part (a) treats each observation within the panel as an individual unit, part (b) refers to the scores of each country in the most recent available year, i.e. 2010, and part (c) presents the country-averages over the entire time period 1981-2010 (or years for which data for a given country are available). Less than $20 \%$ of all observed overperformance scores are below 0.1 and the number is similar for the share of countries with scores below 0.1 in 2010. On the other extreme, scores of 0.9-1 are considerably less common, i.e. they are found in our sample for ca. $6.5 \%$ of all observations and ca. $12.5 \%$ of countries in 2010. The distribution in between the two extreme values of overperformance scores does not demonstrate any particular pattern, confirming considerable variation. The data on average overperformance scores of each country in the period 1981-2010 reveal a single peak at $0.3-0.4$ (slightly more than $15 \%$ of countries), with clearly larger shares of countries corresponding to the lower

\footnotetext{
2 To be specific, as described earlier, the constitutional overperformance measure is, obviously, not limited to studying each non-included in the constitution right separately as the overperformance measure would then come down to a simple $0-1$ gap (it is an aggregated score for all non-included rights).

${ }^{3}$ Countries with constitutions containing 8 or fewer of these 15 rights, but actually respecting half or more of the omitted rights, are defined by Law and Versteeg (2013) as having "modest constitutions" (Law and Versteeg 2013, p. 885).
} 
deciles of overperformance scores (with the median of the distribution, however, at $0.371)$.

We supplement the histograms discussed above with maps showing countries of the world according to their constitutional overperformance scores. Part (a) of Fig. 2 presents the geographical distribution of constitutional overperformance in the most recent available year, i.e. 2010, while part (b) - country averages over the entire time period covered by this study. Countries with more intensive colors score better on constitutional overperformance. Both maps confirm high variation of constitutional overperformance around the globe.

Our data also allow for tracing the detailed patterns and dynamics of constitutional overperformance at the individual country level. It reveals, in particular, that in our sample we can find countries with both a relatively high overperformance level and relatively high variation in this respect (e.g. the Netherlands), countries with low levels of constitutional overperformance and low (or no) variation (e.g. Guatemala, Vietnam, Belarus, Kuwait, Pakistan, or Turkmenistan), as well as many cases in between. In order to test the volatility of constitutional overperformance across counties in our sample for the period 1981-2020, we also analyze the presence of structural breaks within our data, using the methodology developed by Ditzen et al. (2021). Table 1 presents a summary of the obtained results. More than half of the countries included in our sample experienced 1 or no break, while two highest numbers of breaks ( 4 and 5) were identified for only $4 \%$ countries in the sample. Such results suggest that constitutional overperformance is a relatively stable in time phenomenon for the majority of countries included in our sample.

An explanation of cross-country differences in constitutional overperformance can only be based on a consequent multi-variate analysis. Such analysis, conducted in a panel data setting, will also allow to account for overperformance variation in time. Therefore, with this diverse picture of constitutional overperformance at the global and individual-country level in the back of our mind, we now undertake the challenge of searching for factors explaining the distribution and dynamics of this phenomenon.

\section{Potential explanans of constitutional overperformance}

There is no ready-to-use theoretical model of constitutional overperformance in the existing literature. We construct the conceptual framework for our analysis by drawing on the analytical perspective used by works focusing on the enforcement of rights. The latter typically build on theories of repression and apply the rational choice framework, comparing the government's costs and benefits of repressing such rights (e.g. Davenport, 2007; Melton, 2013). According to this approach, the benefits of repression relate to the reduction of any form of dissent and increase in stability, while the costs encompass direct costs of repressing and expected costs of punishment. In the case of constitutional overperformance, the protection of a given right is not required (de jure) by the constitution. This impacts the expected costs of punishment if the right is factually not protected since mechanisms designed for punishing violations of the constitution are in this case not applicable. However, this 
(a) all observations 1981-2010

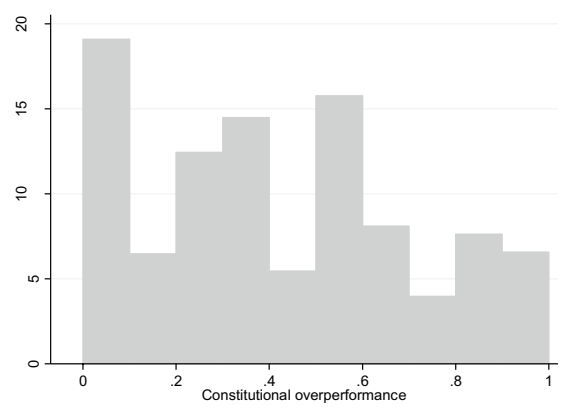

(b) all countries in 2010

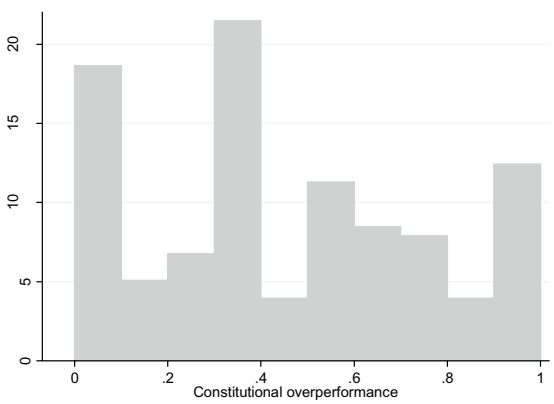

(c) averages for each country 1981-2010 (when data available)

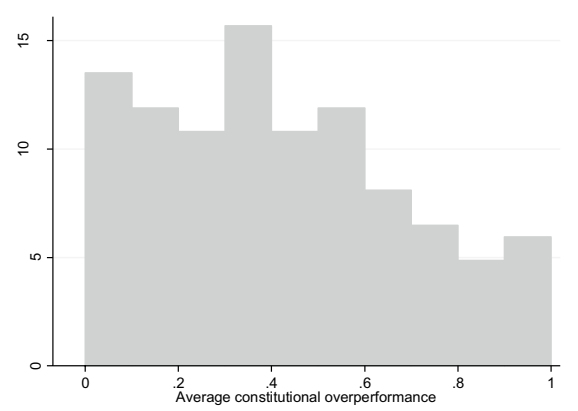

Fig. 1 Distribution of constitutional overperformance scores globally. Source Authors' graphs using Law and Versteeg's (2013) constitutional overperformance data

does not preclude the operation of other punishment mechanisms for failing to protect a given right in practice even if it does not have a de jure equivalent in the country's constitution (for example, international sanctions of a formal/direct or infor$\mathrm{mal} /$ indirect kind, or simply electoral enforcement).

In our exploration of potential factors linked with constitutional overperformance, conducted further in this section, we apply this cost-benefit perspective (focusing on (over)protecting, not repressing rights) and combine it with the theoretical framework used in the literature on institutional and policy diffusion - so as to account for the possible spatial dimension of constitutional overperformance. In the first step, however, we concentrate on the constitution-specific characteristics to explore in more detail the link between constitutional overperformance and the lack of institutionalization problem.

\subsection{Constitution-specific characteristics}

In search for potential explanans of constitutional overperformance we first focus on the constitutions of the countries included in the study and their characteristics.

We expect that the number of rights provisions contained in the country's constitution-named here, following Law and Versteeg (2013), the constitution's degree 
(a) 2010 scores

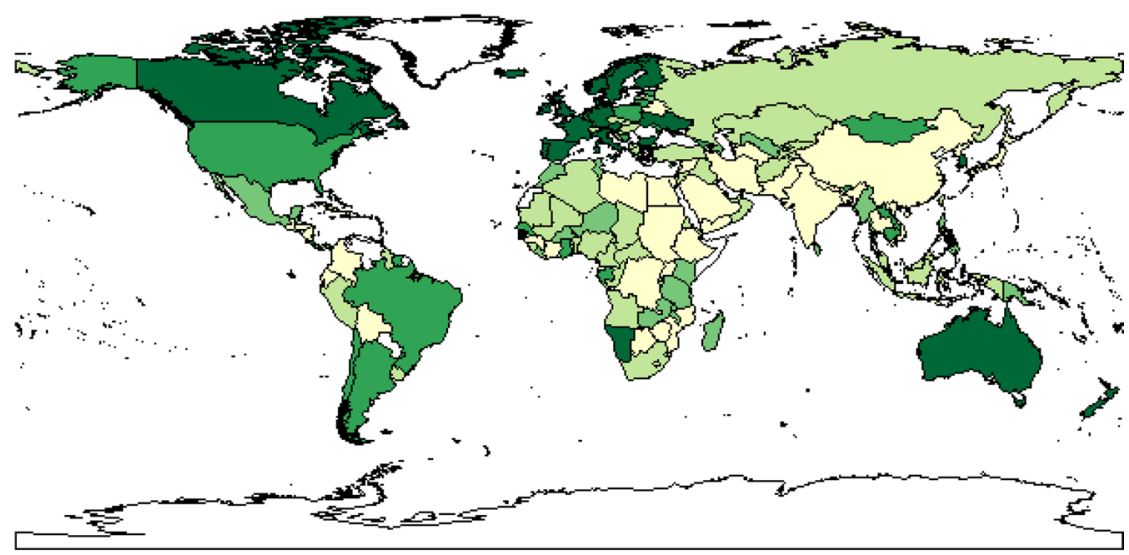

$[0,0.2) \square[0.2,0.4) \square[0.4,0.6) \square[0.6,0.8) \square[0.8,1]$

(b) averages for the period 1981-2010 (when data available)

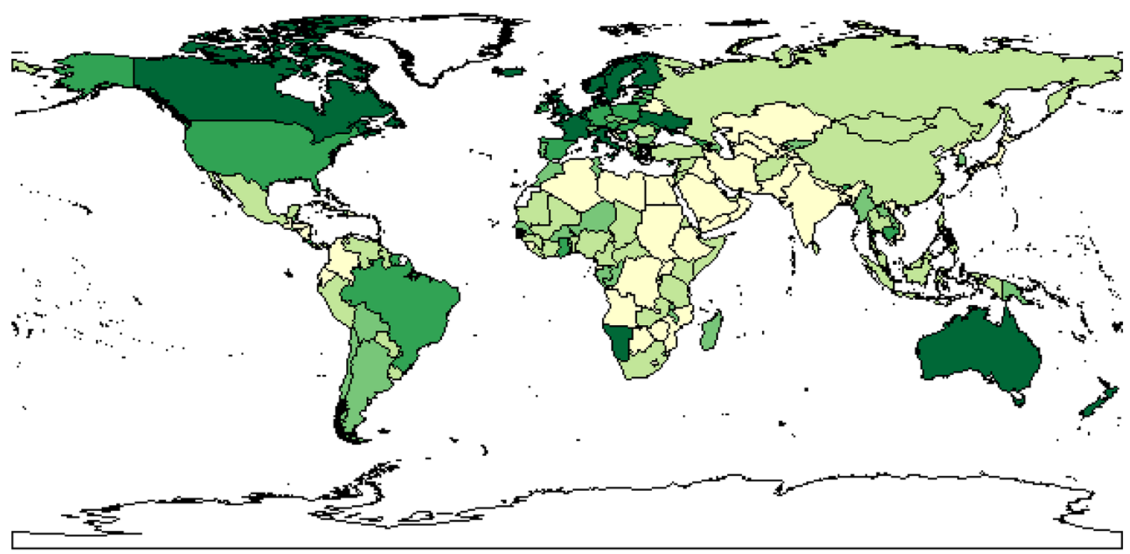

$\square[0,0.2) \quad \square[0.2,0.4) \square[0.4,0.6) \quad \square[0.6,0.8) \quad \square[0.8,1]$

Fig. 2 Geographical distribution of constitutional overperformance. Source Authors' graphs using Law and Versteeg's (2013) constitutional overperformance data

of comprehensiveness-will be a first relevant factor in this respect. ${ }^{4}$ While, as mentioned earlier, constitutional overperformance can be regarded as most impressive

\footnotetext{
${ }^{4}$ Importantly, we treat constitutions' degree of comprehensiveness, i.e. the number of rights that they promise, as exogenous to our framework of analysis. In other words, we do not consider the reasons why countries choose not to include certain rights in their constitutions. Argueably, these factors could also affect the degree of constitutional overperformance as perceived in this paper. It remains a possible future step in the research on constitutional overperfomance to build a bridge between the considerations presented in this paper and studies aiming to explain the factors affecting constitution design, in particular in the area of coding de jure constitutional rights and freedoms.
} 
Table 1 The number of structural breaks in constitutional overperformance level across countries

\begin{tabular}{ll}
\hline Number of breaks in the period 1981-2010 & $\begin{array}{l}\% \text { of } \\
\text { countries }\end{array}$ \\
\hline 0 & 18 \\
1 & 46 \\
2 & 19 \\
3 & 13 \\
4 & 2 \\
5 & 2 \\
\hline
\end{tabular}

Source Authors' calculations

when the number of de jure rights is relatively low, one should also bear in mind that a low number of de jure rights in the constitution leaves greater potential scope for constitutional overperformance in the field of omitted rights. From this point of view constitutional overperformance could be viewed as a consequence of the lack of (de jure) institutionalization in the area of rights and freedoms.

To verify the above hypothesis we include a measure of the constitution's comprehensiveness in our study, relating to the selection of 15 rights that are the basis for the construction of the constitutional overperformance variable. This measure captures the number of de jure rights (belonging to this group of 15) that have been included in a given country's constitution. ${ }^{5}$ We expect the relationship of the comprehensiveness measure with constitutional overperformance to be negative. A first view at the data presented in the bivariate scatter plot in Fig. 3 does not allow for a straightforward conclusion and certainly merits a study of the factors conditioning constitutional overperformance extending beyond the hypothesis that links this phenomenon to deficits of institutionalization.

As mentioned earlier, various studies confirm the inflation of the number of de jure rights included by countries in their constitutions worldwide over the years (e.g. Goderis and Versteeg (2014), who document that the number of rights in national constitutions has more than doubled over 6 decades: from an average of 22.6 in 1946 to 47.2 in 2006). Therefore, we also ask about the relevance of the constitution's age for the degree of constitutional overperformance, expecting that countries with older constitutions might experience more overperformance. Moreover, given a general tendency of constitutional practice to diverge from the formal rules as constitutions get older (Elkins et al., 2009; Strauss, 1996), with the ageing of constitutions de jure-de facto gaps relating to protection of constitutional rights and freedoms increase due to the development of social needs and expectations that diverge from

\footnotetext{
5 A more general approach to comprehensiveness of the constitution has been proposed by Law and Versteeg (2011), capturing whether from the point of view of global constitutionalism a given constitution contains only "generic rights" (i.e. ones which are common to most constitutional systems in the world) or also "esoteric" (i.e. uncommon) ones. A comprehensive constitution contains both types of rights so this measure is inherently correlated with the total number of rights included de jure in a country's constitution. Since our performance measure relates only to the selection of 15 rights and freedoms, the also focus our comprehensiveness measure on this group of rights.
} 
those that were present at the time when these constitutions were adopted. This can imply that, as time passes, a right that was not included in a given constitution, will nevertheless become de facto protected in this country, giving rise to (even more) constitutional overperformance. ${ }^{6}$ While according to Law and Versteeg (2011), the constitution's age is a likely determinant of its comprehensiveness, a simple test of our data (consisting in calculating the correlation coefficient between variables reflecting comprehensiveness of constitutions and their age) confirms that their relation in our setting is not as straight-forward (a relatively low value of this coefficient, -0.15 ) allowing to include both of these variables in our tested specifications and to study other reasons (not only the number of included rights) why older constitutions do not meet the expectations of current societies with regard to protection of constitutional rights, producing in consequence more constitutional overperformance.

\subsection{Country-specific characteristics}

In search for the explanation of the phenomenon of constitutional overperformance we now turn to the literature seeking to identify the determinants of de jure and de facto constitutional rights protection (e.g. Ben-Bassat \& Dahan, 2008, 2016; Elkins et al., 2013; Hill, 2010; Keith et al., 2009; Law \& Versteeg, 2013; Melton, 2013; Metelska-Szaniawska, 2021; Poe et al., 1999). As mentioned earlier, the baseline for our exploration is the analysis of the benefits and costs of protecting de facto rights which have no de jure constitutional equivalents. This gives us the second group of potential explanans of constitutional overperformance-countries' institutional and socio-economic characteristics, which may contribute to higher/lower costs or benefits in this respect.

Among a country's institutional characteristics we consider the following aspects: its democratization level (as well as, alternatively, other characteristics of its sociopolitical system including checks and balances, and the development of civil society), ratification of the International Covenant on Civil and Political Rights or the International Covenant on Economic, Social and Cultural Rights, and de facto independence of the judiciary. ${ }^{7}$ With regard to constitutional overperformance judicial activism in cases relating to constitutional rights practice could be a particularly relevant feature to consider, however cross-country data of such kind, allowing for reliable inter-country comparisons, are not available. Nevertheless, the inclusion of the degree of de facto judicial independence as one of the potential explanans in the study may be a partial solution to this problem as this variable may not only

\footnotetext{
${ }^{6}$ Another consequence can be constitutional underperformance, i.e. that de jure rights included in constitutions are no longer de facto protected. Given our focus on micro-constitutional effects, this observation, however, does not interfere with our argumentation concerning constitutional overperformance.

7 Some of the studies mentioned above focus on the sole presence of judicial review in the constitution. We argue that it is not the mere presence of such mechanism but also its "quality", as expressed by the degree of judicial independence, that matters. Our empirical results support this claim (confirming, in some specifications, the significance of judicial independence, while a simple variable reflecting the presence of judicial review in the constitution proved insignificant in all tested specifications and has been removed from the final model presented here).
} 


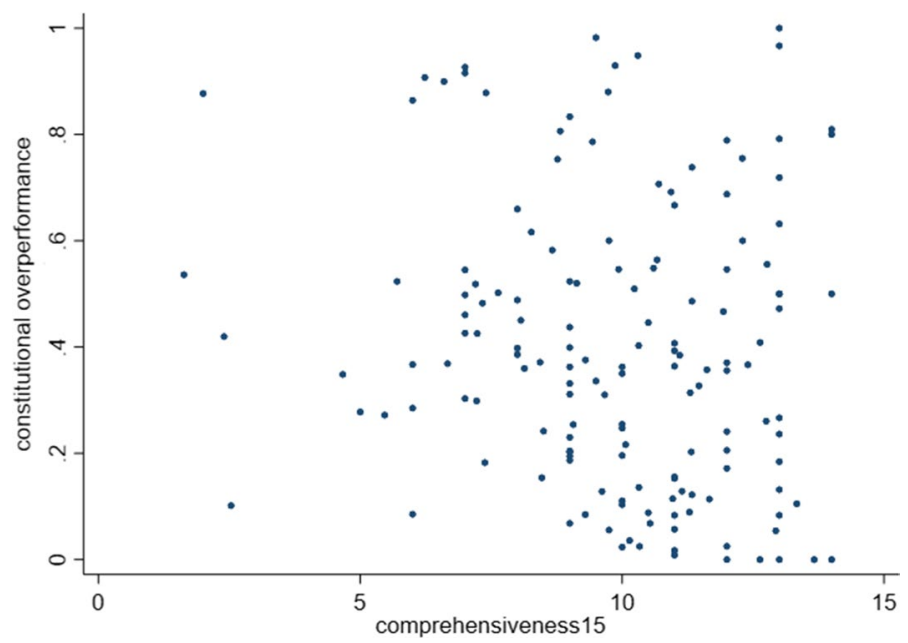

Fig. 3 Comprehensiveness of constitutions and constitutional overperformance. Source Authors' graphs using Law and Versteeg's (2013) constitutional overperformance data

indicate the strength of the constitutional commitment mechanism but also capture the degree of judges' discretion and in this way may also correlate with their scope of activism. ${ }^{8}$ Among the socio-economic characteristics of countries the literature mentioned above suggests to include the following: the presence of a political conflict, the robustness of civil society, economic development level (GDP per capita), population, and ethnic fractionalization.

We expect highly democratic regimes to be more prone than others to upholding rights even when the latter have not been explicitly declared in the constitution. This is, in particular, because the expected costs of a failure to protect these rights are higher in democratic regimes thanks to the presence of electoral enforcement (citizens' may "punish" a government that does not protect their rights by withdrawing their support for its representatives in subsequent elections). A similar line of reasoning can be applied to other factors of countries constraining politicians' discretion and/or increasing their accountability, such as strong checks and balances, or a well-developed civil society. A positive effect for constitutional overperformance is also expected in the case of countries which have ratified the aforementioned international covenants (here the reason is higher expected punishment costs for countries in the event of not overperforming in the area, where these covenants oblige them, under the threat of international sanctions, to enforce certain rights, regardless of whether the latter are present in their national constitutional systems). Subsequent characteristics potentially contributing to a framework conducive for de facto protection of rights with no de jure equivalents are favorable economic conditions and a

\footnotetext{
8 This is not to say that judges, who are not de facto independent, will not exercise discretion. However, one does not expect this to lead to increased enforcement of constitutional rights (in fact, rather the contrary).
} 
relatively more independent judiciary (as a crucial element of the rights enforcement mechanism). Contrarily, as countries plagued by political conflict (including intraand interstate wars), with large and/or heterogeneous populations are more prone to constitutional violations, we expect these factors to contribute negatively to constitutional overperformance.

\subsection{Spatial diffusion effects}

Finally, we propose to take a spatial view at the phenomenon of constitutional overperformance to complete the list of potential explanans of its global patterns. While diffusion of de jure constitutional rights has received considerable attention in the recent literature (e.g. Goderis \& Versteeg, 2014 and sources mentioned therein), the literature on explaining de facto protection of rights through the lens of spatial analysis is much scarcer (e.g. Lewczuk, 2021 on spatial diffusion of de facto civil liberties protection in post-socialist countries). While we would not expect particular spatial effects as regards constitutional underperformance (determined to a great extent by country-specific features), we believe that with regard to constitutional overperformance such mechanisms of diffusion as acculturation, or even competition or learning could be at play.

Literature on institutional and policy diffusion identifies four primary channels or mechanisms of the diffusion process: coercion, competition, learning, and acculturation (Goderis \& Versteeg, 2014). For the case of constitutional overperformance we would not expect that a given country is directly coerced to enforce a right, which it does not include in its constitution, by another country or group of countries. ${ }^{9}$ Countries may however compete for foreign capital or exports by adopting policies or institutions that are attractive to investors and buyers in international markets (Simmons et al., 2006). Protection of constitutional rights is an important pre-condition to secure investment climate and property rights, as well as a transparent legal system, which all contribute to lower costs of doing business for foreign buyers (Law, 2008). This is relevant in particular in the de facto dimension. Competition between countries may therefore also demonstrate itself in the area of constitutional rights protection and in this way diffusion through competition may explain why a country that did not include a de jure right in its constitution, does uphold it in practice.

Constitutional overperformance could potentially also result from yardstick competition between countries - a mechanism, in which agents use the performance of others as a benchmark (see Shleifer, 1985 on regulation of firms; Besley \& Case, 1995 on local fiscal policy; and many other recent studies identifying such mechanism in different settings). The yardstick competition hypothesis in the context of constitutional overperformance rests on the idea that an informational spillover from constitutional performance (and, in particular, its socio-economic effects) in the neighborhood could affect the beliefs of the electorate with respect to their government's behavior in this area. The voters in a given country would then perceive the

\footnotetext{
9 A close case of countries being bound by the provisions of international covenants that its representatives have signed has already been discussed in the previous subsection.
} 
quality and efficiency of their own government by using other governments' performance (and the resulting observable outcomes in terms of socio-economic development) as a yardstick. The presence of this informational externality could generate correlation in constitutional overperformance among neighboring jurisdictions by inducing countries' authorities (interested in maintaining their voters' support) to mimic each other's behavior.

However, it does not have to be that countries compete (either for specific economic benefits or in the context of yardstick competition) with each other, they may also internalize new norms and/or rules of behavior and redefine their interests as a result of the broadly construed process of learning. With regard to constitutional rights this may be the case both in the de jure and in the de facto dimension. This channel of diffusion is likely to demonstrate itself among countries which are geographically close to each other as proximity implies information availability and interaction, both of which spur diffusion (Rogers, 2003) and may also contribute to explaining constitutional overperformance.

Finally, the acculturation channel in the diffusion process, which has its roots in organizational sociology, emphasizes that actors adopt the behavioral patterns of the culture that surrounds them (Goodman \& Jinks, 2004). As Goderis and Versteeg (2014, p. 4) put it, "[s]tates desire to be part of a self-identified group of peers. As a result, they conform to the norms of these peers, regardless of the content of these norms". This may also imply that they comply with certain norms, e.g. constitutional rights, regardless of whether their own legal (or, in our case, constitutionallegal) system expects them to do so. ${ }^{10}$ This could be the final mechanism behind diffusion of constitutional overperformance.

To sum up, based on the above considerations, in our empirical study we ask whether in the event when countries in geographic proximity of a given country de facto respect constitutional rights (no matter whether they are included de jure in their constitutions or not) this country has a higher likelihood of also observing such rights even when their de jure versions are not present in this country's constitution. In other words, this implies seeking the answer to the question, whether (and if so, then to what extent and via which channels) constitutional overperformance is an effect of the diffusion of de facto respect for constitutional rights.

\footnotetext{
${ }^{10}$ We follow here the argumentation of Goderis and Versteeg (2014, p. 4) in noting that such norms will be adopted, however not internalized (as the latter involves learning), resulting in the detachment of outward conformance from internal acceptance and " $<<$ structural decoupling $>>$ between adopted norms and actual practices" (see also Goodman and Jinks 2004). While Goderis and Versteeg (2014, p. 4) further argue that this may contribute to countries not complying with the de jure rights that they adopt (via acculturation) we focus on the inverse possibility, i.e. that rights are de facto enjoyed and not de jure included in constitutions.
} 


\section{Empirical study}

In our empirical tests we first concentrate on the explanations introduced in Sects. 3.1 and 3.2 of the paper (Sect. 4.1) and then turn to study the potential spatial effects (Sect. 4.2). Finally, we present a robustness check of our results using extreme bounds analysis in Sect. 4.3. Depending on specification, our global study encompasses a panel of 95-151 countries of the world, for which data are available, for the period 1981-2010.

\subsection{Panel regression analysis}

The baseline specification involves explaining the level of constitutional overperformance in a given country for a given year (variable name: constitutional_overperformance), defined and measured as described in Sect. 2.1, by a set of potential explanans including: comprehensiveness of the country's constitution relating to those 15 rights, for which constitutional overperformance is measured (comprehensiveness 15); age of the constitution (constitution_age); the country's democratization level (democracy) ${ }^{11}$; ratification of the International Covenant on Civil and Political Rights and/or the International Covenant on Economic, Social and Cultural Rights (covenant); the degree of de facto judicial independence (judicial_independence); the presence of a political conflict (conflict); and economic development$G D P$ per capita $\left(G D P \_p c\right) .{ }^{12}$ Expecting path dependence, we also include lagged constitutional overperformance variables.

In several tested alternative specifications we took a further step towards developing a broader understanding the role of political systems for overperformance in rights protection. This involved substituting the composite indicator of institutionalized democracy by various characteristics of countries' political systems, pertaining to checks and balances and other constraints on power, as well as, more broadly, systems of government. Substituting the composite democracy measure by indicators relating to political systems additionally allowed to include variables related to the development of civil society in the studied countries. While many variables tested in the discussed alternative specifications proved insignificant, the robustness of civil society (civil_society) and strength of checks and balances (checks) confirmed their

\footnotetext{
11 By construction, the indicator of democracy used in this paper, comprises the following aspects: competitiveness of political participation, the openness and competitiveness of executive recruitment, and constraints on the chief executive (Marshall et al., 2014). While constitutional protections of rights and freedoms could constitute important institutionalized constraints on the decision-making powers of chief executives (the latter component of the democracy indicator), they are not explicitly included in the construction of this measure and therefore this independent variable and the dependent variable in the model do not overlap.

12 We do not include the population size and ethnic fractionalization variables as they proved insignificant in all tested specifications. In our estimations we also tested for the potential role of legal origins (using the classification proposed by Chang et al., 2021) for differences in constitutional overperformance between groups of countries. However, since we failed to find meaningful results that would allow for a consistent interpretation of the role this factor, we do not include legal origins in the empirical analysis of constitutional overperformance presented in this paper.
} 
relevance in some regressions and the results pertaining to the alternative specification, where these two variables substitute for the composite democracy variable, are further presented.

Detailed information about the construction of the included variables, as well as sources of data, are provided in Appendix 1. Table 2 presents the descriptive statistics.

Table 3 presents the results of panel data estimations for the ordinary panel-in columns I-II for the basic specification and in columns III-IV for the alternative specification. The Hausman test suggests in both cases that the fixed effects (FE) model should be applied. It has been argued in the literature that FE estimates have an asymptotic bias of order $1 / T$, where $T$ stands for the time period under analysis in years. This is the so-called Nickell bias (Nickell, 1981), resulting from the lack of strict exogeneity in models including lagged dependent variables on the right-hand side of the equation. This bias, however, disappears as $T$ becomes large. Given the fact that $T$ is 30 years in our panel, the bias can be regarded as negligible in our setting. ${ }^{13}$

In order to capture the potential role of constitutional overperformance dynamics over time, in Table 4 we additionally present the estimates of the dynamic panel model obtained using the Arellano-Bond estimator (including 1,2, and 3 lags of the dependent variable). ${ }^{14}$ For all specifications and estimation techniques we obtain significant coefficients on the lagged dependent variables. This finding, together with the significant coefficient on the lagged dependent variable in all columns of Table 3, confirms path dependence of the constitutional overperformance phenomenon.

The results for the basic specification (in columns I-II of Table 3, with the second one presenting results of FE estimations including year fixed effects, ${ }^{15}$ and in columns I-III of Table 4) suggest five particularly relevant explanans of constitutional overperformance- the comprehensiveness of a given country's constitution, its age, the country's democratization level, judicial independence, and presence of political conflicts. The signs on the coefficients for these variables are in line with the expectations presented earlier in the paper: While the first and last variable on the above list are negatively related with overperformance, the remaining ones demonstrate a positive relation. To sum up the first portion of results, countries with higher levels of constitutional overperformance are those which, ceteris paribus, include less de jure rights in their constitutions, have older constitutions, are characterized by

\footnotetext{
${ }^{13}$ Monte Carlo simulation results suggest that in datasets with $\mathrm{T}=30$ the Nickell bias is of the order of $1 \%$ and thus does not constitute a major concern (Judson, Owen 1999).

${ }^{14}$ We tested the inclusion of up to 5 lags of our dependent variable in the dynamic model, however in the estimations for 4 and 5 lags not all of these lags were found significant. We also verified the correctness of the dynamic panel model specifications using Sargan test for overidentifying restrictions. For all model setups we did not reject the null hypothesis that the overidentifying restrictions were valid, what supports the chosen model specification.

${ }^{15}$ We include year fixed effects so as to account for potential global trends in overperformance over time. We, however, only identify 3 of these effects to be significant at a $\%$ level (for 1985, 1988, and 1990).
} 
independent high courts, experience higher democratization levels ${ }^{16}$ and less political conflicts. Other factors proved either irrelevant (as with ratifying international covenants) or discussable (as with economic development—significant in Table 4, but not in Table 3) in these first settings.

The results obtained for the alternative specification, presented in Columns III-IV of Table 3 and IV-VI of Table 4, lead to conclusions that are generally in line with those presented so far but also allow to enrich them. Most interestingly, they demonstrate that constitutional overperformance is significantly higher in countries with a more robust civil society, what confirms that an active civil society is not only an effective mechanism constraining potential abuse of power but may also act as informal social control and in this way contribute to protecting rights in some societies even when they are not included in these countries' constitutions. The institutional constraints on power, as measured by the checks variable, prove mostly insignificant in this setting, nevertheless we wait with interpreting this finding for the results of our spatial panel estimations. We opt for the same approach with regard to the insignificance of political conflict in columns III-IV of Table $3 .{ }^{17}$

\subsection{Spatial analysis}

Implementation of spatial analysis entails various advantages. If there is spatial interdependence in the panel data and an ordinary (aspatial) model has been estimated, this is likely to result in biased and inefficient coefficient estimates because of the omitted variable problem. The use of spatial techniques allows to counteract this problem by inclusion of spatial components in the model. The existence of spatial autocorrelation in our data set has been confirmed by two formal tests, i.e. the Baltagi, Song, Jung and Koh C.1 conditional test ${ }^{18}$ and the Baltagi, Song and Koh LM-H one-sided joint test. ${ }^{19}$ Based on this evidence, our presumption concerning the diffusion of de facto constitutional protection of rights (through various channels discussed in Sect. 3.3) can be considered valid and justifies undertaking spatial analysis of constitutional overperformance.

The spatial econometric specification used to analyze the mechanisms of the diffusion of constitutional overperformance is a spatial panel fixed effects (FE) model based on the Spatial Durbin Error Model Structure (SDEM), i.e.:

\footnotetext{
${ }^{16}$ We check the robustness of our results concerning the role of democracy by substituting the composite democracy measure with the simpler Bjoernskov-Rode index (Bjoernskov, Rode, 2020) relating to the electoral component of democracy. Following Cheibub et al. (2010) this approach classifies a country as democratic if free and fair elections were concluded and if there was a peaceful turnover of legislative and executive offices following these elections The conclusions from our estimations remain unchanged following this modification.

${ }^{17}$ We have also conducted a similar analysis for the three categories of rights included in the study personal interity rights, civil and political freedoms, and socio-economic rights. As the results revealed no meaningful differences between these categories, we refrain from presenting them in the paper.

${ }^{18}$ LM statistics take the value of 187.89 (model I), 151.7 (model II), 177.76 (model III), and 144.4 (model IV), indicating the presence of spatial dependence in error terms.

19 The LM-H statistics take the value of 59.511(model I), 23.32 (model II), 57.327 (model III), and 22.994(model IV), indicating the presence of random regional effects and spatial autocorrelation.
} 
Table 2 Descriptive statistics

\begin{tabular}{llrlll}
\hline Variable name & Observations & Mean & Standard deviation & Minimum & Maximum \\
\hline constitutional_overperformance & 4382 & 0.405 & 0.296 & 0 & 1 \\
comprehensiveness15 & 6240 & 8.004 & 4.514 & 0 & 15 \\
constitution_age & 5180 & 30.815 & 66.995 & 0 & 795 \\
democracy & 4441 & 0.588 & 0.361 & 0 & 1 \\
covenant & 5658 & 0.685 & 0.454 & 0 & 1 \\
judicial_independence & 4803 & 0.166 & 1.443 & -2.975 & 3.293 \\
conflict & 4886 & 0.184 & 0.387 & 0 & 1 \\
GDP_pc & 5260 & 3.349 & 0.703 & 1.736 & 5.034 \\
checks & 4697 & 2.579 & 1.717 & 0 & 18 \\
civil_society & 4647 & 0.630 & 0.305 & 0.014 & 0.984 \\
\hline
\end{tabular}

Source Authors' calculations

$$
Y=X \beta+W X \theta+u,
$$

with the error term given as:

$$
u=\rho W u+\varepsilon,
$$

where $Y$ is the dependent variable (constitutional_overperformance), $X$ is the set of independent variables (identical to the set of explanatory variables included earlier in the ordinary panel regressions), $W$ is the spatial weight matrix, $W X \theta$ represents spatial lags of independent variables, and $\rho W u$ - the spatial error. The choice of this model structure has been made taking into account both econometric and theoretical arguments. Firstly, our estimation strategy-from general to specific-as recommended in the literature (see e.g. Kopczewska et al., 2015), led to such choice of the model's functional form. ${ }^{20}$ Secondly, SDEM is the spatial model structure which allows for modeling local spillovers ${ }^{21}$ (LeSage, 2014), which in our case could reflect the diffusion of de facto protection of constitutional rights and, therefore, constitutional overperformance. We use two spatial weight matrices in our

\footnotetext{
${ }^{20}$ The estimation process involved successive reduction of elements from the most general model, which included specific effects, i.e. random or fixed effects (individual, time or two-way), as well as all spatial components. This strategy implied taking decisions (in a firmly established order) concerning firstly specific effects, then spatial components, further variables and their lags, and finally the error term structure.

${ }^{21}$ A spillover is a phenomenon that occurs when a causal relationship between the $r$-th characteristic/ action of the entity/agent located at position $i$ in space exerts significant influence on the outcomes/decisions/actions of an agent located at position $j$ (LeSage, 2014). Two types of spillovers can be distinguished: global and local ones. One of the key characteristics of global spillovers is that changes in one country cause a sequence of adjustments in, potentially, all countries in the sample and, as a result, a new long-run steady state equilibrium arises. On the other hand, local spillovers do not cause such kind of endogenous interaction outcomes. It is assumed that local spillovers occur when it is primarily the values of explanatory variables in neighboring countries that exert an impact on the value of the dependent variable in a given country (LeSage, 2014). Therefore, such approach and model specification will enable us to capture the nature of (potential) diffusion of constitutional overperformance among countries remaining in geographic proximity.
} 


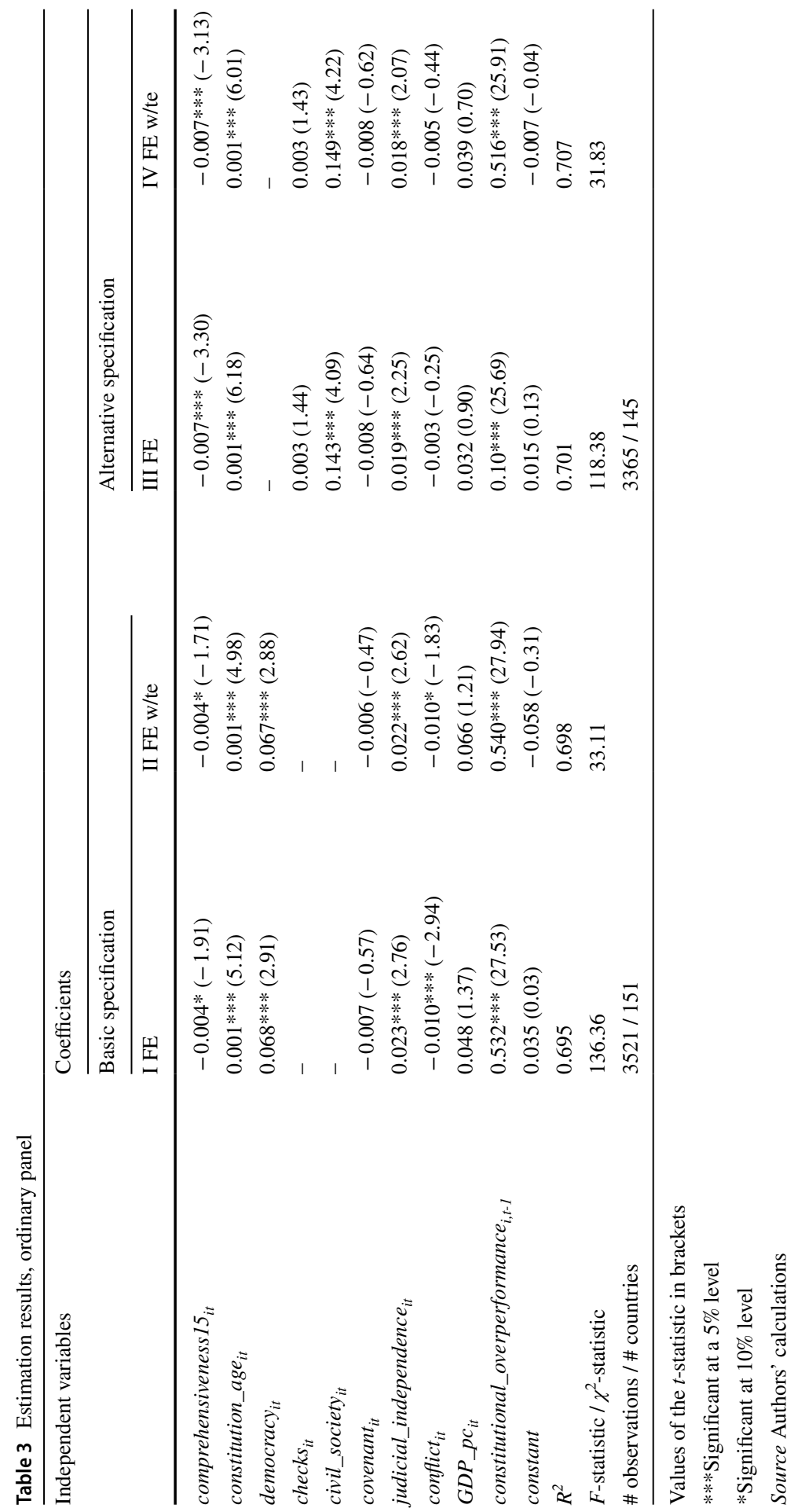




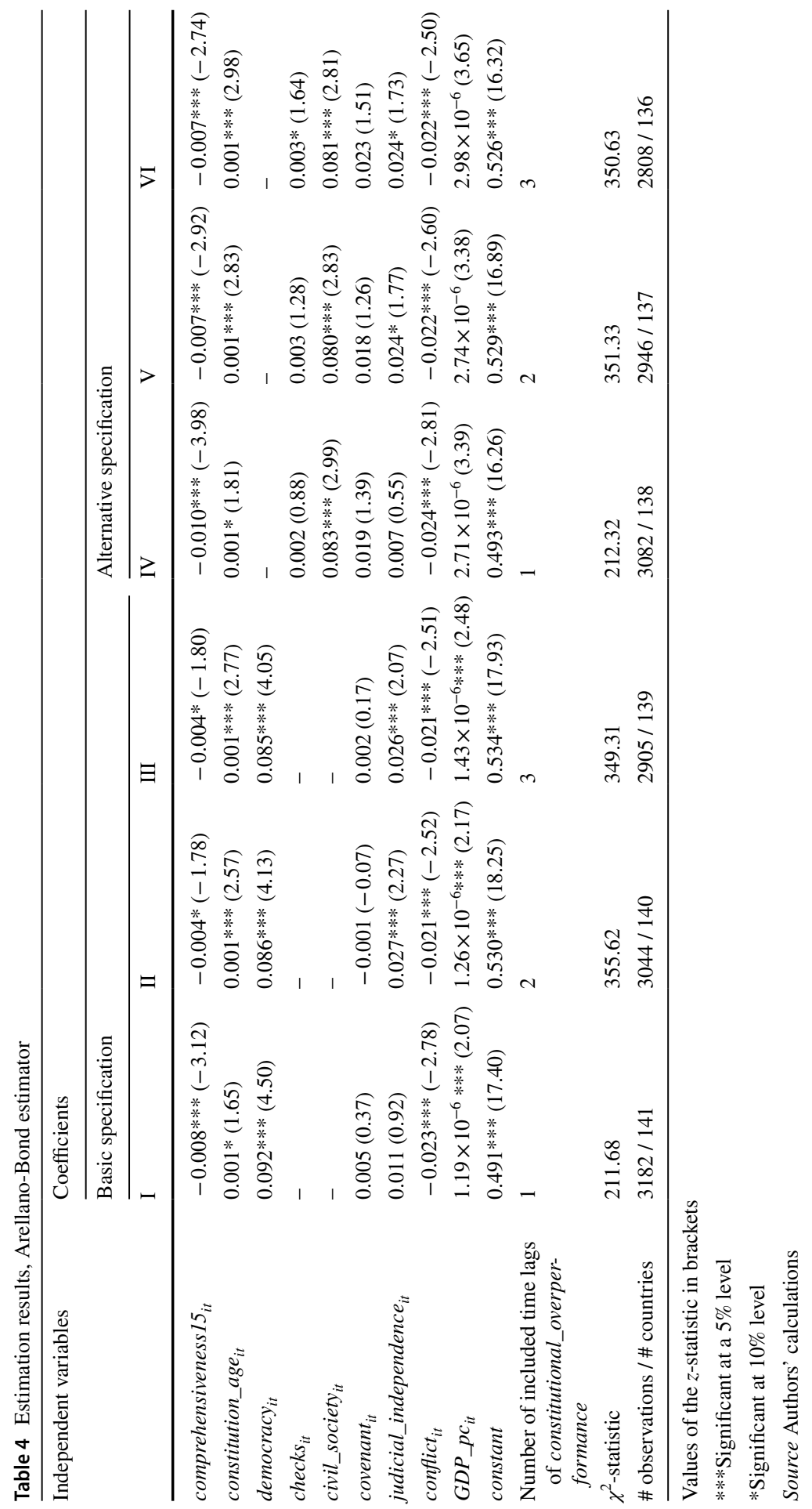


study - the inverse distance matrix with weights equal $1 / d_{i j}$, where $d_{i j}$ stands for distance between country $i$ and country $j$, and the inverse squared distance matrix with weights equal $1 / d_{i j}^{2}$. The inverse distance matrix expresses linear relations of neighbors with all territorial units (the strength of this relationship is proportional to the distance between units). As a result, by using such matrix it is possible to test global spatial interaction effects without taking into account local clusters. The main assumption of the inverse squared-distance matrix states that relations between neighbors are non-linear i.e. they vary more than proportionally to distance between countries. This matrix form allows testing for both local effects (accounting for the fact that neighboring countries tend to be strongly related in terms of their economy, culture and history) and global effects (by assigning non-zero weights to all units) (Kopczewska et al., 2015). The choice of the aforementioned spatial weight matrices allows to take into consideration not only interactions between all countries, but also to account for local clusters that may play a crucial role in the diffusion process. ${ }^{22}$

In our spatial model interpretation of the obtained coefficients is based on the analysis of the so-called direct and indirect effects (impacts). It is assumed that if the value of a given variable changes in a particular unit (in our case country), one may observe not only a change in the value of the dependent variable for this unit (a direct effect), but also in the value of the dependent variable for other units (the indirect effect) (Elhorst, 2010). In a spatial Durbin error model the coefficient estimate of that explanatory variable $(\beta)$ represents its direct effect, whereas its indirect effect is captured by the coefficient estimate of its spatial lagged value $(\theta)$ (LeSage and Pace, 2009). Parameter $\rho$ from Eq. (2) is also subject to interpretation. A significant and positive $\rho$ reflects that fluctuations of short-term spillovers tend to be similar in neighboring locations. On the other hand, a significant and negative parameter indicates the existence of competitive mechanisms of reaction in different countries to common shocks modeled by the error term (Kopczewska et al., 2015).

Due to the fact that the data used in our spatial estimation are characterized by a shorter time span than in case of non-spatial approach, ${ }^{23}$ we need to re-address the question of potential existence of Nickell bias in our results. As a robustness check we follow the approach recommended by Davis and Vadlamannati (2013) and we estimate the model using the lagged dependent variable GMM approach with instrumental variables, where instruments consist of weighted averages of the remaining countries' exogenous variables. Application of this method enables to overcome the Nickell bias resulting from including lagged dependent variables in our spatial model.

\footnotetext{
${ }^{22}$ Other spatial weight matrices are also applied in spatial panel studies, such as e.g. the contiguity, or common border lengths matrix. The inverse distance and inverse squared distance matrices fit best the context of our study. However, recent spatial econometric literature highlights that in fact the choice of the spatial weight matrix is not a crucial factor for proper specification of the estimated model, i.e. that well-fitted models with different forms of spatial matrices are not likely to produce estimates and inferences that substantially differ from each other (LeSage and Pace, 2014).

${ }^{23}$ Using the same time-span as in non-spatial estimation would require a large number of imputations for missing data, what could affect the reliability of the results, therefore our spatial analysis covers the period 1995-2010.
} 
Table 5 presents the outcome of spatial panel estimations relating to the basic and alternative specifications studied earlier in the ordinary (aspatial) setting, for both the inverse distance and the inverse squared-distance weight matrices (insignificant spatial lags have been excluded). In this spatial model setting we include two additional variables allowing to capture potential competition of countries for economic benefits from increased de facto rights protection (proxied by the level of foreign direct investment-FDI-in neighboring countries) and the potential yardstick competition spatial effect (proxied by the level of human development-HDI-in such countries). ${ }^{24}$ We include both spatial lags of FDI and HDI in the regression so as to compare the results for these two potential channels of diffusion of constitutional overperformance through competition.

The obtained results indicate the presence of significant effects of both typesdirect and indirect ones. With regard to the first ones, the findings once again strongly confirm the relevance of countries' political systems, i.e. their democratization level as indicated by the basic specification (Columns I and II of Table 5), and the robustness of their civil societies based on the alternative specification (Columns III and IV). The latter also brings a novel result confirming, for the first time, that countries with stronger checks and balances as such (i.e. with formally more strongly constrained political power) experience more constitutional overperformance. This result, however, comes at the expense of obtaining insignificant coefficients for the judicial independence variable in this alternative setting. For the basic specification the obtained results suggest the significance of judicial independence, however only at an $85 \%$ confidence level. Comprehensiveness of the countries' constitutions reveals its significance in the spatial setting for all tested models and specifications (Columns I-IV), just as presence of a political conflict and the constitution's age. We cannot confirm the relevance of economic conditions of a country, nor ratification of international covenants, for its constitutional overperformance in this more sophisticated framework.

In addition to the direct effects mentioned above, the presented analysis provides evidence of an indirect effect of HDI on constitutional overperformance. From the results obtained for in all columns of Table 5 one may conclude that the level of constitutional overperformance in a given country is positively related to an increase in welfare of its neighboring countries proxied in terms of life expectancy, education and standard of living. We believe that this could be a sign of diffusion of constitutional overperformance due to yardstick competition between countries. Observing an increase in welfare in a neighboring country, voters may be willing to exert pressure on their government to catch up. One of the strategies that the decision-makers may adopt in such circumstances is broader respect for constitutional rights, even if they have not been specified in the given country's constitution, in order to mimic the successful neighbor's policy. We, however, do not obtain a similar confirmation for the second potential channel of diffusion of constitutional overperformance

\footnotetext{
${ }^{24}$ In the case of both of these variables, FDI and $H D I$, we include their first lags so as to capture the effect that observing the economic or socio-economic situation in a neighboring country in a given period may have on constitutional overperformance of the given country in the next period.
} 


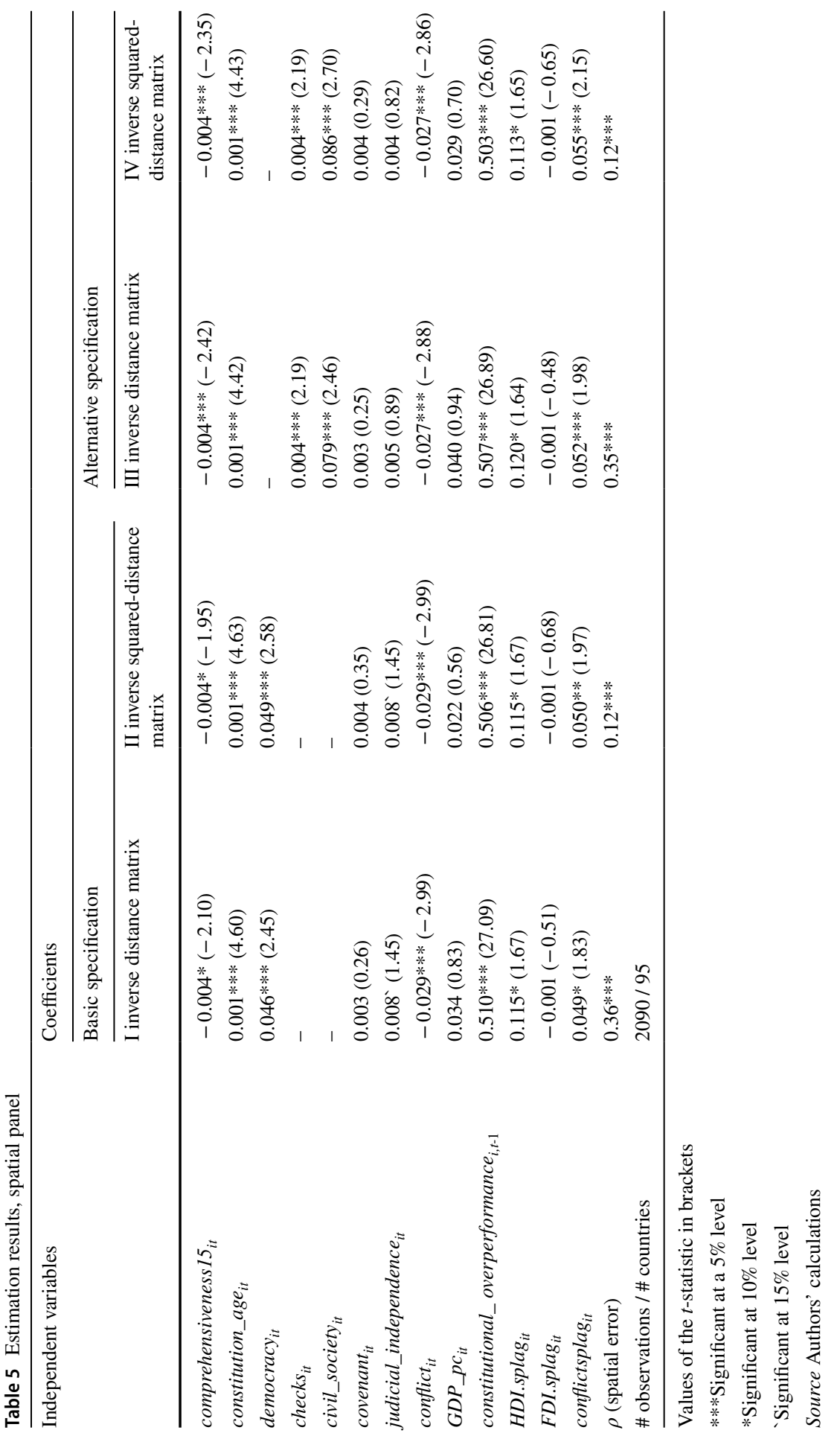


through competition. Insignificance of the spatial lag of FDI indicates that competition of countries for benefits associated with attracting foreign investors does not matter for overperforming in the area of constitutional rights protection. ${ }^{25}$

From the selection of variables exerting direct effect on constitutional overperformance only presence of political conflict is found to also indirectly affect the degree of this overperformance. We attribute this finding to an additional motivation for the government to protect certain rights that arises from political conflict encountered by a neighboring state, even if these rights have not been included in that country's constitution, in order to calm social attitudes and counteract the potential spreading of the conflict to its own territory.

Finally, the positive and significant $\rho$ parameter in all columns of Table 5 indicates that short-term overperformance fluctuations exhibit similar patterns in neighboring countries. In other words, one may conclude that values of constitutional overperformance vary in the same direction in neighboring countries. This finding may be regarded as another piece of evidence confirming the spatially-dependent nature of constitutional overperformance, which may be explained by competition between countries concerning the level of constitutional rights protection but also other mechanisms of diffusion described earlier in Sect. 3.3, such as acculturation and learning. The discussed results do not vary with changes of the spatial weight matrix, i.e. including global or local effects, what additionally confirms their validity.

\subsection{Robustness check}

To provide a robustness check of the obtained results, we enrich our study with Leamer's extreme bound analysis (EBA). EBA, being a sensitivity test, enables one to examine the extent to which the dependent variable in a regression is robustly associated to the set of included independent variables. In other words, this procedure checks whether the obtained model results are robust to minor changes in the list of explanatory variables.

Table 6 presents the outcomes of EBA for both the basic and alternative model specifications. The table includes the values of the extreme bounds $\left(\beta_{\max }\right.$ and $\beta_{\min }$ ) on the coefficients for each independent variable, together with the respective $t$-statistics. The results clearly confirm that the set of explanatory variables, which we apply in specifications studied throughout this paper, robustly explains the dependent variables of our interest (constitutional overperformance).

\footnotetext{
25 One cannot rule out the possibility that competition for foreign investment would be a significant mechanism behind constitutional overperformance for the specific group of developing countries only, however as the spatial approach presented here is unsuitable for verifying this hypothesis, we leave it as an open question on the agenda for future research.
} 


\section{Conclusion}

The focus in this paper on three categories of potential factors explaining divergent experience of countries in the world as regards constitutional overperformance could be summarized, in short, in the form of a single question: Is constitutional overperformance simply a result of (too) little text, or can it be explained by other factors, such as, e.g., the country's degree of democratization, judges' discretionary powers, economic development level, presence of political conflicts, or mechanisms of diffusion between countries ('peer pressure')? Based on the obtained results we can conclude that the amount of text, or in other words the strength of (de jure) institutionalization, matters to some extent but a more convincing factor is the type of regime, namely democratic regimes are indeed more prone to upholding rights even when the latter have not been explicitly stipulated in the constitution. This relates, in particular, to the robustness of civil societies (social pressure), but also to some extent to the formal checks and balances, i.e. institutional pressure (as revealed by the more reliable spatial panel estimation) and the related concept of judicial independence. Among other factors, presence of a political conflict hinders constitutional overperformance, while the age of the constitution is a contributing factor. Last but not least, mechanisms of diffusion based on competition (in particular in the case when neighboring countries become socio-economically more successful, spurring a mechanism of yardstick competition between countries), as well as possibly acculturation and learning, have also confirmed their significant role in fostering the spread of constitutional overperformance.

Some of the characteristics of countries and their constitutions have already been confirmed by other studies mentioned earlier in this paper (in particular, Law \& Versteeg, 2013) as being linked to (or causing) countries' underperformance in the sphere of constitutional rights and freedoms. With this study-to the best of our knowledge being the first one in the constitutional economics literature focusing on this topic - we identified a set of factors enhancing our understanding of the

Table 6 Results of Leamer's EBA

\begin{tabular}{|c|c|c|c|c|}
\hline Variable of interest & $\beta_{\max }$ & t-statistic & $\beta_{\min }$ & t-statistic \\
\hline comprehensiveness $15_{i t}$ & -0.02 & $-16.93 * * *$ & -0.03 & $-16.14 * * *$ \\
\hline constitution_age $e_{i t}$ & $1 \times 10^{-3}$ & $14.02 * * *$ & $7 \times 10^{-4}$ & $13.29 * * *$ \\
\hline democracy $_{i t}$ & 0.37 & $31.60 * * *$ & 0.26 & $19.89 * * *$ \\
\hline checks $_{i t}$ & 0.05 & $20.91 * * *$ & 0.03 & $13.22 * * *$ \\
\hline civil_society $_{i t}$ & 0.49 & $13.89 * * *$ & 0.28 & $17.63 * * *$ \\
\hline covenant $_{i t}$ & 0.15 & $15.09 * * *$ & 0.14 & $13.80 * * *$ \\
\hline judicial_independence $_{i t}$ & 0.58 & $24.89 *$ & 0.09 & $14.89 * * *$ \\
\hline conflict $_{i t}$ & -0.12 & $-12.74 * * *$ & -0.26 & $-18.03 * * *$ \\
\hline$G D P_{\_} p c_{i t}$ & 0.18 & $15.76^{* * *}$ & 0.11 & $18.14 * * *$ \\
\hline
\end{tabular}

****Significant at a $5 \%$ level

*Significant at $10 \%$ level

Source Authors' calculations 
inverse phenomenon of constitutional overperformance. In this way we believe that we contributed a missing piece to the rich picture of factors and mechanisms behind enforcement of constitutional rights and freedoms.

\section{Appendix 1: Description of variables and data sources}

\begin{tabular}{|c|c|c|}
\hline Variable name & Description & Data source \\
\hline checks & $\begin{array}{l}\text { A measure of the presence and } \\
\text { strength of checks and balances } \\
\text { in the country's model of } \\
\text { government }\end{array}$ & $\begin{array}{l}\text { Beck et al. (2001, data release from } \\
\text { 2012) }\end{array}$ \\
\hline civil_society & $\begin{array}{l}\text { An indicator of the robustness } \\
\text { of civil society, understood as } \\
\text { one that enjoys autonomy from } \\
\text { the state and in which citizens } \\
\text { freely and actively pursue their } \\
\text { political and civic goals }\end{array}$ & Coppedge et al. (2016) \\
\hline comprehensiveness 15 & $\begin{array}{l}\text { A measure of comprehensive- } \\
\text { ness of a constitution capturing } \\
\text { the number of rights from the } \\
\text { selection of } 15 \text { rights being } \\
\text { the basis for the constitutional } \\
\text { overperformance measure (for } \\
\text { a list see text) that a country } \\
\text { contains in its constitution }\end{array}$ & Law and Versteeg (2013) \\
\hline constitution_age & $\begin{array}{l}\text { The age of a country's constitu- } \\
\text { tion (in years) }\end{array}$ & Elkins et al. (2014) \\
\hline conflict & $\begin{array}{l}\text { A binary variable indicating the } \\
\text { presence of an armed conflict }\end{array}$ & $\begin{array}{l}\text { Gleditsch et al. (2002) as updated } \\
\text { by Pettersson and Wallensteen } \\
(2015)\end{array}$ \\
\hline constitutional_overperformance & $\begin{array}{l}\text { A measure of constitutional } \\
\text { overperformance for } 15 \text { rights } \\
\text { and freedoms (for a list see } \\
\text { text), i.e. the proportion of } \\
\text { these rights omitted from a } \\
\text { country's constitution that was } \\
\text { actually respected ( } 0 \text { indicates } \\
\text { that the country did not uphold } \\
\text { any of them, while } 1 \text { indicates } \\
\text { perfect respect for all them in a } \\
\text { given year) }\end{array}$ & Law and Versteeg (2013) \\
\hline
\end{tabular}




\begin{tabular}{|c|c|c|}
\hline Variable name & Description & Data source \\
\hline covenant & $\begin{array}{l}\text { Ratification of the International } \\
\text { Covenant on Civil and Political } \\
\text { Rights and/or the Interna- } \\
\text { tional Covenant on Economic, } \\
\text { Social and Cultural Rights (the } \\
\text { general measure takes the value } \\
\text { of } 1 \text { in case both have been } \\
\text { ratified, } 0.5 \text { in case when one } \\
\text { of them has been ratified, and } 0 \\
\text { in the cases of not ratifying any } \\
\text { of them; in some specifica- } \\
\text { tions indicated in the text the } \\
\text { measure relates to only one of } \\
\text { the covenants and is binary) }\end{array}$ & UN OHCHR (2019) \\
\hline democracy & $\begin{array}{l}\text { A composite indicator of institu- } \\
\text { tionalized democracy }\end{array}$ & Marshall et al. (2014) \\
\hline$H D I$ & Human Development Index & UN (2016) \\
\hline judicial_independence & $\begin{array}{l}\text { De facto high court independ- } \\
\text { ence indicator measuring the } \\
\text { extent to which, when ruling in } \\
\text { cases that are salient to the gov- } \\
\text { ernment, a high court makes } \\
\text { decisions that merely reflect } \\
\text { government wishes regardless } \\
\text { of its sincere view of the legal } \\
\text { record }\end{array}$ & Coppedge et al. (2016) \\
\hline$F D I$ & $\begin{array}{l}\text { Log of foreign direct investment } \\
\text { (net inflows in current US } \\
\text { dollars) }\end{array}$ & The World Bank (2016) \\
\hline$G D P_{-} p c$ & Log of GDP per capita & Feenstra et al. (2015) \\
\hline
\end{tabular}

Acknowledgements The authors would like to thank participants of 2018 Annual Meeting of the American Law and Economics Association (ALEA) in Boston, 2018 European Public Choice Society (EPCS) Annual Conference in Rome, 2018 Annual Meeting of the Public Choice Society in Charleston, 2017 Political Economy of Democracy and Dictatorship (PEDD) Conference in Muenster, 2016 and 2017 European Association of Law and Economics (EALE) Annual Conferences in Bologna and London, where earlier versions of this paper were presented, for helpful comments. We also thank Mila Versteeg for sharing the Law and Versteeg (2013) dataset.

Funding This research is funded by the National Science Centre of Poland (project \#2014/13/B/ HS4/00402).

\section{Declarations}

Conflict of interest The authors have no relevant financial or non-financial interests to disclose.

Open Access This article is licensed under a Creative Commons Attribution 4.0 International License, which permits use, sharing, adaptation, distribution and reproduction in any medium or format, as long as you give appropriate credit to the original author(s) and the source, provide a link to the Creative Commons licence, and indicate if changes were made. The images or other third party material in this article are included in the article's Creative Commons licence, unless indicated otherwise in a credit line to the 
material. If material is not included in the article's Creative Commons licence and your intended use is not permitted by statutory regulation or exceeds the permitted use, you will need to obtain permission directly from the copyright holder. To view a copy of this licence, visit http://creativecommons.org/licen ses/by/4.0/.

\section{References}

Beck, T., Clarke, G., Groff, A., Keefer, P., \& Walsh, P. (2001). New tools in comparative political economy: The Database of Political Institutions. World Bank Economic Review, 15(1), 165-176.

Ben-Bassat, A., \& Dahan, M. (2008). Social rights in the constitution and in practice. Journal of Comparative Economics, 36, 103-119.

Ben-Bassat, A., \& Dahan, M. (2016). Constitutional commitment to social security and welfare policy. Review of Law and Economics, 12(1), 165-201.

Besley, T., \& Case, A. (1995). Incumbent behavior: Vote seeking, tax setting and yardstick competition. American Economic Review, 85, 25-45.

Bjoernskov, C. (2015). Constitutional property rights protection and economic growth: Evidence from the post-communist transition. Constitutional Political Economy, 26(3), 247-280.

Bjoernskov, C., \& Rode, M. (2020). Regime types and regime change: A new dataset on democracy, coups, and political institutions. Review of International Organizations, 15, 531-551.

Blume, L., Müller, J., \& Voigt, S. (2009). The economic effects of direct democracy - A first global assessment. Public Choice, 140, 431-461.

Buchanan, J. M., \& Tullock, G. (1962). The calculus of consent logical foundations of constitutional democracy. The University of Michigan Press.

Chang, Y. C., Garoupa, N., \& Wells, M. T. (2021). Drawing the legal family tree: An empirical comparative study of 170 dimensions of property law in 129 jurisdictions. Journal of Legal Analysis, 13(1), 231-282.

Cheibub, J. A., Gandhi, J., \& Vreeland, J. R. (2010). Democracy and dictatorship revisited. Public Choice, $143,67-101$.

Chilton, A. S., \& Versteeg, M. (2016). Do constitutional rights make a difference? American Journal of Political Science, 60(3), 575-589.

Cingranelli, D. L., Richards, D., \& Clay, C. K. (2014). The CIRI human rights dataset. http://www.human rightsdata.com

Coppedge, M., Gerring, J., Lindberg, S. I., Skaaning, S.-E., Teorell, J., Altman, D., Bernhard, M., Fish, M. S., Glynn, A., Hicken, A., Knutsen, C. H., Marquardt, K., McMann, K., Miri, F., Paxton, P., Pemstein, D., Staton, J., Tzelgov, E., Wang, Y., Zimmerman, B. (2016). V-Dem [Country-Year/Country-Date] Dataset v6.2. Varieties of democracy (V-Dem) project.

Davenport, C. (2007). State repression and the domestic democratic peace. Cambridge University Press.

Davies, R. B., \& Vadlamannati, K. C. (2013). A race to the bottom in labor standards? An empirical investigation. Journal of Development Economics, 103, 1-14.

Ditzen, J., Karavias, Y., \& Westerlund, J. (2021). Testing and estimating structural breaks in time series and panel data in stata. arXiv:2110.14550 [econ.EM]. Working paper: https://arxiv.org/pdf/2110.14550.pdf

Elhorst, J. P. (2010). Applied spatial econometrics: Raising the bar. Spatial Econometric Analysis, 5(1), 9-28.

Elkins, Z., Ginsburg, T., Melton, J. (2014). The Comparative Constitutions Project. Data available at http:// www.comparativeconstitutionsproject.org/

Elkins, Z., Ginsburg, T., \& Simmons, B. (2013). Getting to rights: Treaty ratification, constitutional convergence, and human rights practice. Harvard International Law Journal, 54(1), 61-95.

Elkins, Z., Ginsburg, T., \& Melton, J. (2009). The endurance of national constitutions. Cambridge University Press.

Feenstra, R. C., Inklaar, R., \& Timmer, M. P. (2015). The next generation of the Penn World Table. American Economic Review, 105(10), 3150-3182.

Gleditsch, N. P., Wallensteen, P., Eriksson, M., Sollenberg, M., \& Strand, H. (2002). Armed conflict 19462001: A new dataset. Journal of Peace Research, 39(5), 615-637.

Goderis, B., \& Versteeg, M. (2014). The diffusion of constitutional rights. International Review of Law and Economics, 39, 1-19.

Goodman, R., \& Jinks, D. (2004). How to influence states: Socialization and international human rights law. Duke Law Journal, 54(3), 621-703. 
Hausman, J. A., \& Taylor, W. E. (1981). Panel data and unobservable individual effects. Econometrica, 49(6), 1377-1398.

Hill, D. W., Jr. (2010). Estimating the effects of human rights treaties on state behavior. The Journal of Politics, 72(4), 1161-1174.

Judson, R. A., \& Owen, A. L. (1999). Estimating dynamic panel data models: A guide for macroeconomists. Economics Letters, 65(1), 9-15.

Keith, L. C., Tate, C. N., \& Poe, S. C. (2009). Is the law a mere parchment barrier to human rights abuse? The Journal of Politics, 71(2), 644-660.

Kopczewska, K., Kudła, J., \& Walczyk, K. (2015). Strategy of spatial panel estimation: Spatial spillovers between taxation and economic growth. Applied Spatial Analysis and Policy, 10(1), 77-102.

Law, D. S. (2008). Globalization and the future of constitutional rights. Northwestern University Law Review, 102(3), 1277-1349.

Law, D. S., \& Versteeg, M. (2011). The evolution and ideology of global constitutionalism. California Law Review, 99(5), 1163-1257.

Law, D. S., \& Versteeg, M. (2013). Sham constitutions. California Law Review, 101, 863-952.

LeSage, J. (2014). What regional scientists need to know about spatial econometrics. The Review of Regional Studies, 44(1), 13-32.

LeSage, J., \& Pace R. K. (2009). Introduction to spatial econometrics. CRC Press, Taylor and Francis Group.

LeSage, J., \& Pace, R. K. (2014). The biggest myth in spatial econometrics. Econometrics, 2, 217-249.

Lewczuk, A. (2019). Human rights protection and foreign direct investment: The case of post-socialist countries. The Economics of Transition and Institutional Change, 27(4), 1009-1030.

Lewczuk, A. (2021). Are civil liberties contagious? Analysis of determinants of de facto civil rights protection in post-socialist countries. Constitutional Political Economy, 32(2), 187-217.

Marshall, M. G., Gurr, T. R., \& Jaggers, K. (2014). Polity IV project. Political regime characteristics and transitions, 1800-2013. Center for Systemic Peace, http://www.systemicpeace.org

Melton, J. (2013). Do constitutional rights matter? The relationship between de jure and de facto human rights protection, working paper, http://citeseerx.ist.psu.edu/viewdoc/download?doi=10.1.1.375.9784\& rep $=$ rep $1 \&$ type $=$ pdf

Melton, J., \& Ginsburg, T. (2014). Does de jure judicial independence really matter?: A reevaluation of explanations for judicial independence. Journal of Law and Courts, 2(2), 187-217.

Metelska-Szaniawska, K. (2021). Post-socialist constitutions: The de jure - de facto gap, its effects and determinants. Economics of Transition and Institutional Change, 29(2), 175-196.

Metelska-Szaniawska, K., \& Lewkowicz, J. (2021). Post-socialist "illiberal democracies": Do de jure constitutional rights matter? Constitutional Political Economy, 32(2), 233-265.

Nickell, S. (1981). Biases in dynamic models with fixed effects. Econometrica, 49(6), 1417-1426.

Persson, T., \& Tabellini, G. (2003). The economic effects of constitutions. The MIT Press.

Pettersson, T., \& Wallensteen, P. (2015). Armed conflicts, 1946-2014. Journal of Peace Research, 52(4), $536-550$.

Poe, S. C., Tate, C. N., \& Keith, L. C. (1999). Repression of the human right to personal integrity revisited: A global cross-national study covering the years 1976-1993. International Studies Quarterly, 43(2), 291-313.

Rogers, E. M. (2003). Diffusion of innovation (5th ed.). Free Press.

Shleifer, A. (1985). A theory of yardstick competition. Rand Journal of Economics, 16(3), 319-327.

Simmons, B. A., Dobbin, F., \& Garrett, G. (2006). Introduction: The international diffusion of liberalism. International Organization, 60(4), 781-810.

Spruk, R. (2016). Institutional transformation and the origins of world income distribution. Journal of Comparative Economics, 44, 936-960.

Strauss, D. A. (1996). Common law constitutional interpretation. The University of Chicago Law Review, 63(3), 877-935.

The World Bank (2016). World Development Indicators database.

UN (2016). Human Development Reports. United Nations Development Programme, http://hdr.undp.org/en/ data

UN OHCHR (2019). Ratification of 18 International Human Rights Treaties Database. The United Nations Office of the High Commissioner for Human Rights. http://indicators.ohchr.org/

Voigt, S. (2021). Mind the gap - analyzing the divergence between constitutional text and constitutional reality. International Journal of Constitutional Law, moab060.

Voigt, S. (2011). Positive constitutional economics II - a survey of recent developments. Public Choice, 146(1-2), 205-256. 
Voigt, S., Gutmann, J., \& Feld, L. P. (2015). The effects of judicial independence 10 years on: Cross-country evidence using an updated set of indicators. European Journal of Political Economy, 38, 197-211.

Publisher's Note Springer Nature remains neutral with regard to jurisdictional claims in published maps and institutional affiliations. 